\title{
Spatial Pattern and Habitat Requirements of Galaxias maculatus in the Last Un-Interrupted Large River of Patagonia: A Baseline for Management
}

\author{
Marina Tagliaferro ${ }^{1}$, Analía Quiroga ${ }^{1} \&$ Miguel Pascual $^{1}$ \\ ${ }^{1}$ CONICET - Centro Nacional Patagónico, Argentina \\ Correspondence: Marina Tagliaferro, CONICET - Centro Nacional Patagónico, Bld. Brown 2915, Puerto \\ Madryn, Chubut, Argentina. Tel: 54-280-445-1024 Int. 288. E-mail: azulmarinita@gmail.com
}

Received: December 26, 2013 Accepted: January 20, 2014 Online Published: January 26, 2014

doi:10.5539/enrr.v4n1p54 URL: http://dx.doi.org/10.5539/enrr.v4n1p54

\begin{abstract}
The relationship between the native Galaxias maculatus and environmental variables was studied in 52 sites located along $306 \mathrm{~km}$ of the main stemof the Santa Cruz River, the second largest river in Argentinean Patagonia. The abundance varied along the river, with three general sections clearly defined: upstream with minimum abundance increasing towards midstream and downstream areas. Distance to the sea and river wet width which were negatively significantly associated with abundance,and maximum depth explained the abundance in a polynomial shape - achieving a total explanation of $41.1 \%$. The best predictive model also combined the river sinuosity.Our results suggested that the construction of two proposed hydroelectric dams will modify these variables, which might generate changes in G. maculatus distribution. The information obtainedduring the present study represents valuable information for conservation management of this species.
\end{abstract}

Keywords: habitat, Galaxiid, large river, Patagonia, GLM, dams

\section{Introduction}

In lotic ecosystems, biological communities are structured primarily by physical habitat (Hynes, 1970). Habitat disturbance has an important role in constraining the types of ecological processes and patterns observed in streams (Ward \& Stanford, 1983; Power et al., 1988; Resh et al., 1988; Poff \& Ward, 1990). Understanding the habitat requirements of each species and the relationship with environmental variables is critical to comprehending their ecology in natural systems and to evaluate possible change scenarios (Argent, Bishop, Stauffer, Carline, \& Myers, 2003; Jowett, Richardson, \& Bonnett, 2005).

Galaxiid srepresent one of the most abundant native fish species from Southern Hemispherefreshwaters (McDowall, 1990). Each galaxiid species has a habitat preference, being defined by the main variables identified as affecting its distribution: local and maximum depth, channel width, substrate size (Ault \& White, 1994; Allibone \& Townsend, 1997), current speed (García, González, \& Habit, 2012; Bonnet \& Sykes, 2002), and proximity to the sea (Bonnet \& Sykes, 2002; Eikaas, Kliskey, \& McIntosh, 2005). The type of habitat used by one species might also change in the presence of invasive species or along ontogeny (Hale, Downes, \& Swearer, 2008; Jellyman \& McIntosh, 2008).

The most abundant galaxiid species in Patagonia, Galaxias maculatus, whichexhibits two life-history strategies (land-lockedand diadromous individuals; McDowall, 1990; Carrea et al., 2013) was studied along $306 \mathrm{~km}$ of the main stem of the Santa Cruz River. Since two hydroelectric dams will be built soon and little is known about the local wildlife and the environment the aim of this study was to identify environmental variables that may affect the abundance of G. maculatus and the shape of the response by using generalized linear models (GLM). Secondly, we sought to identify the model that best predictedthe likely responses of the fish to possible change scenarios.

The information on the un-degraded river condition is generally limited or absent, which make it difficult to determine appropriate restoration strategies. We expect the present research to generate useful information to evaluate conservation and management strategies. 


\section{Methods}

\subsection{Study Area}

The Santa Cruz River $\left(50^{\circ} \mathrm{S} ; 70^{\circ} \mathrm{W}\right)$ originates in two oligotrophic to ultra-oligotrophic large glacial lakes, Viedma and Argentino, and flows uninterrupted for $382 \mathrm{~km}$ across the Patagonian plateau to drain into the Atlantic Ocean (Figure 1; Brunet et al., 2005). The river has an average discharge of $691 \mathrm{~m}^{3} \mathrm{~s}^{-1}$ (min. $278.1 \mathrm{~m}^{3}$ $\mathrm{s}^{-1}$ in Septemberand max. $1,278 \mathrm{~m}^{3} \mathrm{~s}^{-1}$ in March), which is highly predictable due to a glacial dominated flow regime (Tagliaferro, Miserendino, Liberoff, Quiroga, \& Pascual, 2013). Mean water temperature is $9{ }^{\circ} \mathrm{C}$ with maxima registered in January $\left(15^{\circ} \mathrm{C}\right)$ and minima in July $\left(3^{\circ} \mathrm{C}\right)$.

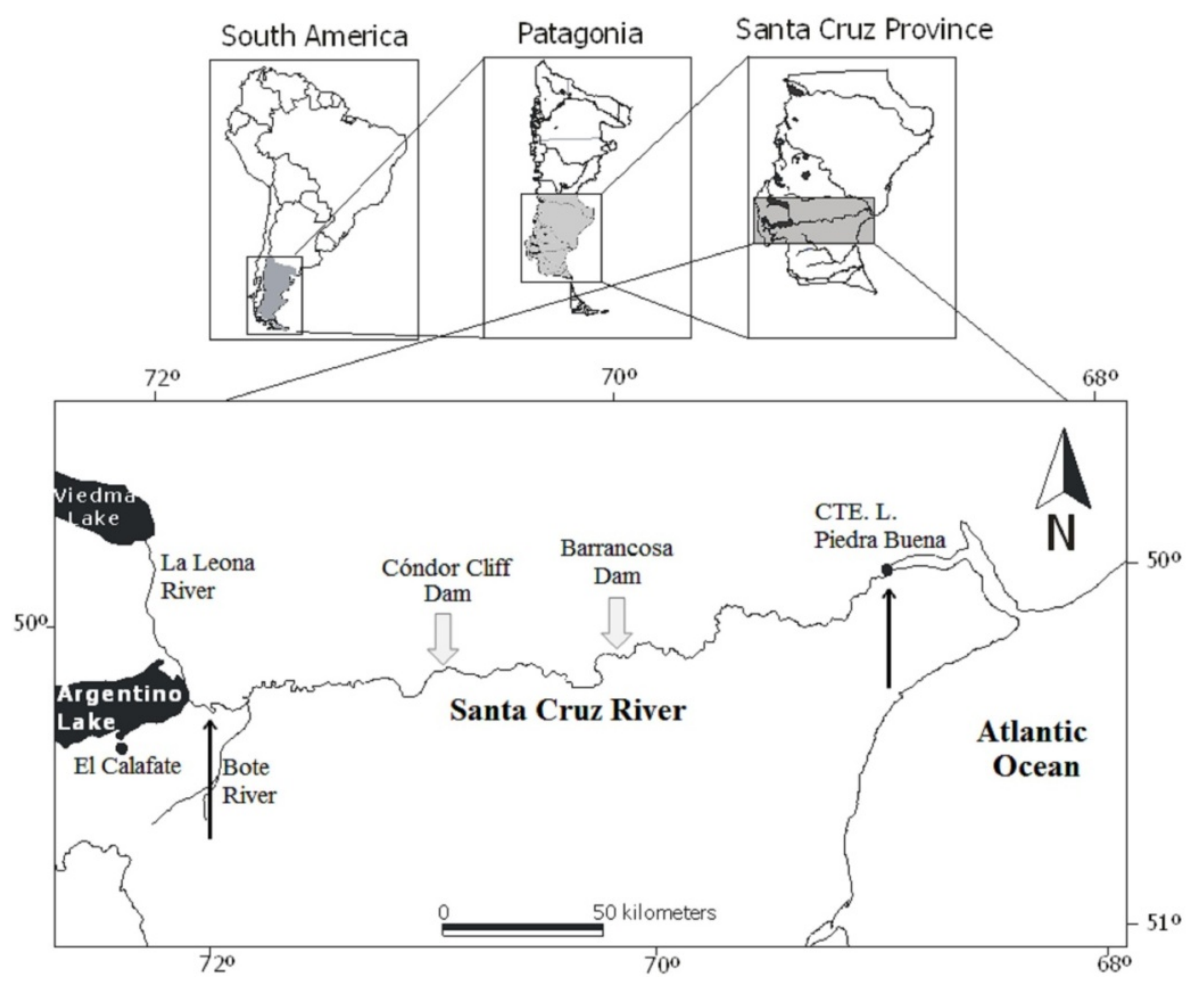

Figure 1. Map of the Santa Cruz River, Patagonia Argentina

Sampling sites are located between Charles Fuhr Bridge and Cte. L. Piedra Buena Town (between arrows).

\subsection{Environmental Variables}

A total of 17 variables were measured at each of the 52 sites along the river, including water and river physical characteristics, dissolved matter, and chlorophyll-a concentration on biofilms. Macro-scale variables of the river (i.e. altitude, bankfull and wet width, current speed, and bathymetry) were measured either continuously or every 300 meters. Wet and bankfull widths were measured using a laser distance meter (TruPulse 200). Altitude and position were measured using an Oregon 550 Garmin GPS and from a digital elevation map, SRTM, 90 m pixel. The sinuosity was estimated as the ratio between the geographic distance and the river distance between pairs of points separated by $500 \mathrm{~m}$ (river distance). The bathymetry was recorded with a Lowrance LCX-15M Techosounder. Local variables, within a 15 meters radius from the sampling point (e.g. dissolved oxygen, depth, current speed, substrate size) were measured at each of the 52 sites following Gordon et al. (2004). Average depth was calculated from 3 measurements within the sampling area. Surface current speed was obtained by timing a half-submerged plastic cup over a distance of 5 meters at each sampling site. Temperature, conductivity and dissolved oxygen were measured using an YSI 85 multi-parameter probe. Substrate size composition was estimated following the Wolman Pebble count procedure (Wolman, 1954), by walking upstream along a zig-zag line across a working area of 100 meters long and 2 to 5 meters wide and measuring the width (the second largest axis) of 50 pieces randomly chosen. A standard area of $11 \mathrm{~cm}^{2}$ was scratched for biofilm from each of three randomly selected rocks (widthrange 5 to $30 \mathrm{~cm}$ ) at each site and stored in a filter, from which chlorophyll a concentration was estimated (APHA, 1994). Water samples of $500 \mathrm{ml}$ were collected below the surface, 
filtered using a $47 \mathrm{~mm}$ diameter $\mathrm{GF} / \mathrm{F}$ Munktell filter, and preserved at $-10{ }^{\circ} \mathrm{C}$ to estimate total suspended solids. In the lab samples were dried at $60{ }^{\circ} \mathrm{C}$ for $24 \mathrm{~h}$, weighed and burned at $500{ }^{\circ} \mathrm{C}$ for $4 \mathrm{~h}$ to assess suspended organic and inorganic matter.

\subsection{Sampling}

We sampled fish during September 2010 (low flowperiod) in 52 sites at intervals of $6 \mathrm{~km}$ along the Santa Cruz River (Figure 1). The uppermost site was located in Charles Fuhr (9.8 km downstream from Lake Argentino) and the lowermost site was located in Comandante Luis Piedra Buena, close to the river'sestuary and $315.8 \mathrm{~km}$ from LakeArgentino.We captured fish using standard single-passelectrofishing procedures from the littoral zone to depths of $0.7 \mathrm{~m}$. The equipment used was a Smith-Root LR-24 electrofisher set to a frequency of $90 \mathrm{~Hz}$ and a pulse width of $3 \mathrm{~ms}$. At each site, a $100 \mathrm{mtransect}$ was sampled following a zig-zag track.Fish were euthanized with an overdose of MS222 and stored in a portable freezer at $-18^{\circ} \mathrm{C}$. At the laboratory, all fish were counted, length-measured with a digital caliper $(0.01 \mathrm{~mm}$ nearest unit), and weighed on a Mettler PC 440 Delta Range balance ( $0.003 \mathrm{~g}$ nearest unit).

\subsection{Data Analysis}

Abundancedata of G. maculatus and environmental variables at each site were arranged in a matrix, on which correlations andmultiple collinearity between variables were evaluated. Autocorrelations between abundances were assessed by using variograms and the comparison of residuals. Data over-dispersion was adjustedby using a scale Poisson distribution. Generalized Additive Models (GAMs) were applied in order to define the set of the environmental non-redundant variables that describe G. maculatus distribution along the Santa Cruz River during the period of study using the 'mgcv' library in the R statistical software (R Development Core Team, 2012). Once the shape of the response was identified, GLMs were applied to the set of data, since these tool provide a more direct and robust technique to evaluate the goodness of fit and to interpret the results (Guisan \& Zimmermann, 2000). Model selection was performed using multi-model inference "MuMIn" (Barton, 2013) and by a stepwise proceeding. Validation graphs (e.g., residuals versus fitted values, QQ-plots and residuals versus the original explanatory variables) were plotted in order to detect the existence of any pattern and possible model mis-specification.To evaluate the accuracy of the predictive model a leave-one-out cross-validation method was used. Observed and expected values were used to estimate the percentage of error of each estimation. The median of the set of 51 estimations were used to compare prediction models.

\section{Results}

A total of 1,183 individuals were captured with a range of length $(40-90 \mathrm{~mm})$ and weight $(0.5-9 \mathrm{~g})$. The distribution of fish showed a high abundance of $G$. maculatus at downstream and midstreamareas whichdecreasedupstream (Figure 2). 61.6\% of the fish population was located in midstream areas which corresponded to $144 \mathrm{~km}$ of the river (including the sites where the dams will be placed); the downstream area (48 $\mathrm{km}$ ) sheltered $25.5 \%$; while in upstream areas $12.9 \%$ of G. maculatus population was found along $114 \mathrm{~km}$.

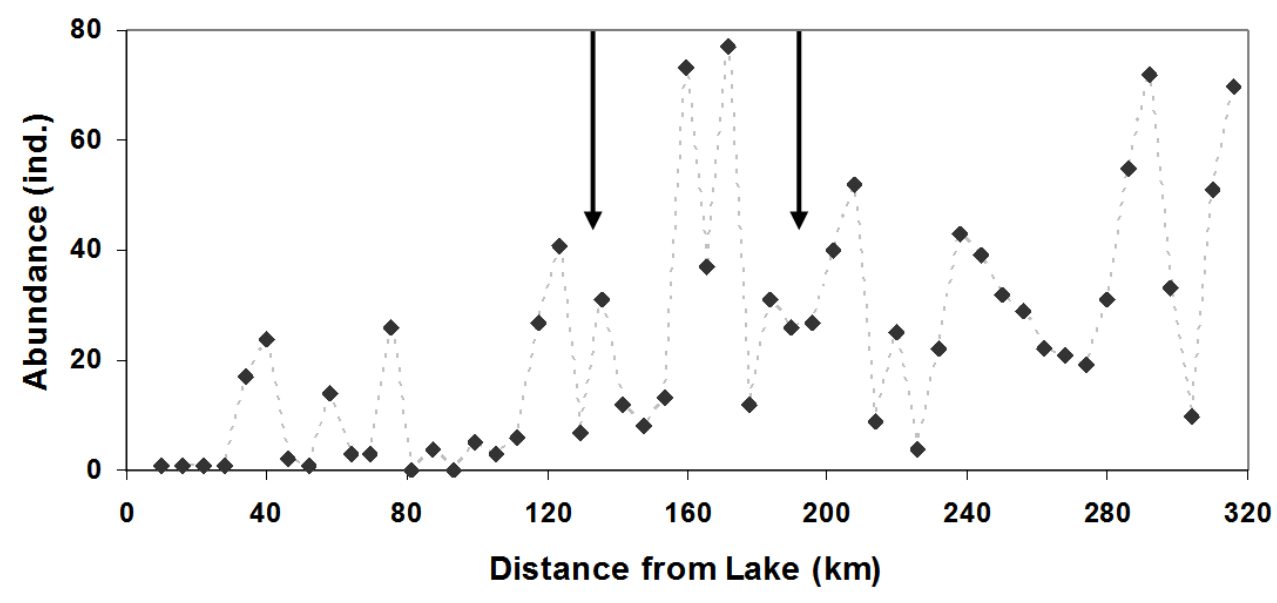

Figure 2. Abundance of G. maculatus among the 52 sampling sites located $6 \mathrm{~km}$ from each other 
Table 1. Physico-chemical variables measured at the sampling sites. Mean, standard deviation, and range of variables are consigned

\begin{tabular}{llll}
\hline Variable & Mean & Std.Dev. & Range \\
\hline Sinuosity & 1.3 & 0.2 & $1.1-2.0$ \\
Slope & 0.6 & 0.2 & $0.1-0.9$ \\
Bankfull $(\mathrm{m})$ & 188.6 & 40.0 & $110-281$ \\
River wet width (m) & 139.4 & 34.1 & $80-216$ \\
Gravel bar $(\mathrm{m})$ & 48.0 & 28.0 & $6-158$ \\
Maximum depth $(\mathrm{m})$ & 5.7 & 3.0 & $2.3-19.8$ \\
Current speed $\left(\mathrm{m} \mathrm{s}^{-1}\right)$ & 0.3 & 0.2 & $0-0.9$ \\
Conductivity $\left(\mu \mathrm{S} \mathrm{cm}^{-1}\right)$ & 26.6 & 1.9 & $22.8-31$ \\
Substrate particles size $(\mathrm{mm})$ & 78.1 & 25.5 & $15.5-147.5$ \\
Temperature $\left({ }^{\circ} \mathrm{C}\right)$ & 6.9 & 1.4 & $4.7-11.0$ \\
pH & 5.8 & 0.3 & $5.0-6.5$ \\
Dissolved oxygen $\left(\mathrm{mg} \mathrm{L}^{-1}\right)$ & 12.3 & 0.7 & $10.6-15.4$ \\
Suspended inorganic matter $\left(\mathrm{mg} \mathrm{L}^{-1}\right)$ & 22.2 & 19.0 & $5.2-117.0$ \\
Suspended organic matter $\left(\mathrm{mg} \mathrm{L}^{-1}\right)$ & 3.1 & 2.2 & $0.6-12.8$ \\
Chlorophyll-a concentration $\left(\mu \mathrm{g} \mathrm{cm}^{-2}\right)$ & 5.6 & 7.4 & $0.2-33.8$ \\
\hline
\end{tabular}

Environmental characteristics of the Santa Cruz River are summarized in Table 1. No patterns were identified that could determine different sections or reaches (covering from 6 to $30 \mathrm{~km}$ ) based on environmental variables. Some environmental variables remain fairly invariant along the river (slope and dissolved oxygen), other showed a smooth gradient (temperature and conductivity), whereas others showed variability at the local scale (e.g., chlorophyll-a, inorganic matter, substrate size, depth).

Few variables showed a significant correlation or multiple collinearity and were removed from the analysis. Both the correlation value and the response of G. maculatus to the variableswere tested. When both variables showed a significant relationship with fish abundance (using both GAMs and GLM), the one with the lower multiple collinearity value was selected. Only the non-redundant variables were left: river wet width (ww), maximum depth (md), substrateparticle size (pe), sinuosity (sin), dissolved oxygen (od) and distance to Lake Argentino (d). GLM models components and explanations are synthesized in Table 2. The best model selected to explain the $G$. maculatusdistribution included the river wet width, distance from the lake and the maximum depth (polynomial), explaining $41.1 \%$ of the variance and producing an output not significantly different to the full model. While linear relationships were found with distance from the river headwaters (positive) and river wet width (negative), the response to maximum depth was quadratic, decreasing rapidly to a depth of 10 meters, being relatively stable and low at greater depths (Figure 3). The models selected under cross-validationpermitted explanation and prediction of changes in the abundance of G. maculatus along the Santa Cruz River with a 52.8 to $64.3 \%$ percentage of error (Table 2). The best prediction model included the polynomial (base 2) relationship of maximum depth, sinuosity, wet width and distance to Lake Argentino (Figure 4). 

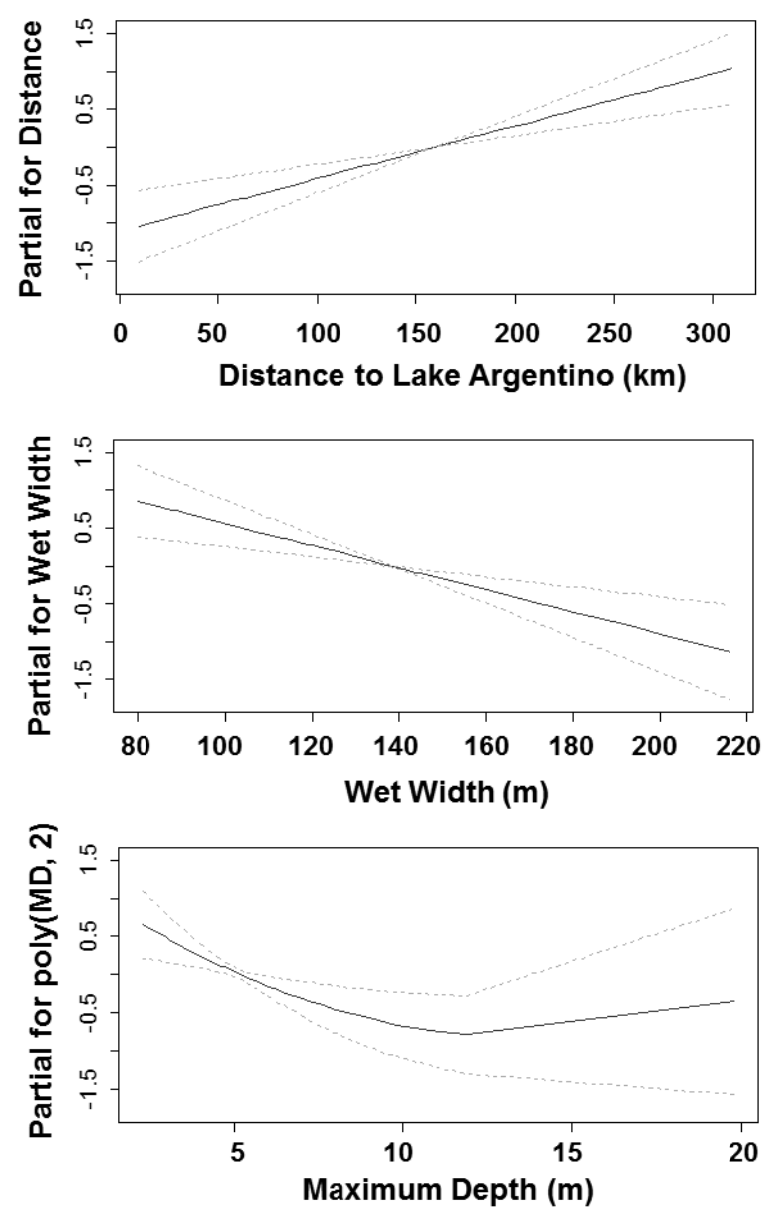

Figure 3. Response of G. maculatus abundance to model selected environmental variables

Table 2. Evaluation of alternative models to explain G. maculatus distribution and prediction errors

\begin{tabular}{lllllllll}
\hline Model & Polynomial -2 & Lineal & Res.Dev & df & Expl.Dev & p & Med. error & Perc. 90\% \\
\hline Full & d, w, m, s, p, o & & 514,9 & 38 & 49,2 & & 64,3 & 419,9 \\
m1 & d, w, m, s, p & o & 558,2 & 39 & 45,0 & ns & 61,9 & 347,4 \\
m2 & d, w, m, s, p & & 558,5 & 40 & 45,0 & ns & 55,9 & 347,2 \\
m3 & d, w, m, p & s & 572,1 & 41 & 43,6 & ns & 62,7 & 400,2 \\
m4 & d, w, m, s & p & 558,6 & 41 & 44,9 & ns & 53,6 & 347,6 \\
m5 & d, w, m, s & & 560,5 & 42 & 44,8 & ns & 52,8 & 351,1 \\
m6 & m, s & d, w & 577,8 & 44 & 43,1 & ns & 59,7 & 376,2 \\
m7 & m & d, w & 598,1 & 46 & 41,1 & ns & 59,6 & 527,0 \\
m8 & - & d, w & 710,8 & 48 & 29,9 & 0,02 & 60,5 & 618,7 \\
Null & & $\sim 1$ & 1014,1 & 50 & - & $* *$ & 63,4 & 1516,5 \\
\hline
\end{tabular}

Each model is compared with the previous one. Expl.Dev: deviance explain by the model. Bold letters indicate significant contribution $(\mathrm{p}<0.05)$ to the model. The letters ns indicate non-significant difference with the previous model; df are the degree of freedom; Med. error is the error related to the median; and the Perc. $90 \%$ is the percentile $90 \%$ of the median. Variables: distance to the lake (d), river wet width (w), maximum depth (m), river sinuosity (s), susbstrate size composition (p), dissolved oxygen (o). 


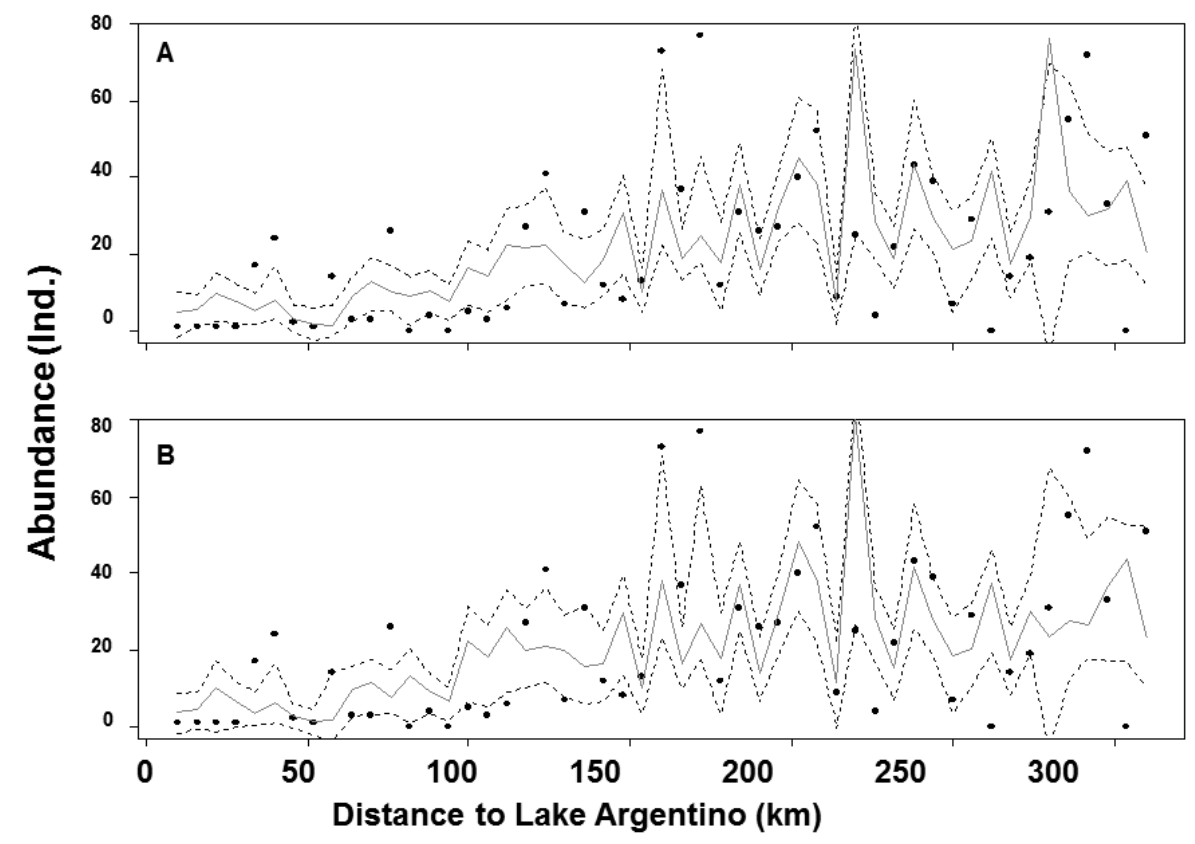

Figure 4. Predictions models for G. maculatus distribution along the Santa Cruz River

Dashed lines indicate the model error (Table 2). Model A: includes distance to the Lake Argentino, river wet width, and maximum depth; model B also includes river sinuosity.

\section{Discussion}

The imminentloss of habitat due to human-induced changes along the watercourses has been extensively studied. However, in several studies on native fish populations, the absence of a baseline is a major problem when identifying management and conservation strategies (Brown, 2000; Bonnett \& Sykes, 2002; Baker \& Smith, 2007). In the present study we identify valuable information on the associations between native fish and habitat. This information includes the direction of the relationship and the shape and formulating prediction models prior to the hydroelectric damconstruction.

In the Patagonia, G. maculatus occupies a vast rangeof lotic and lentic environments: lakes, mountain streams and large plateau rivers. Though habitat use in each of these places differs (García et al., 2012; Montoya, Jara, Solis-Lufí, Colin, \& Habit, 2012), because of its nature, it coincides in being low speed and shallow waters,sometimes associated with vegetation (Colin, Piedra, \& Habit, 2012). In concordance with other authors who have conducted research on New Zealand counterparts, an association with river width, maximum depth (Bond \& Lake, 2003; Baker \& Smith, 2007; Akbaripasand, Nichol, Lokman, \& Closs, 2011) and a negative influence of distance from stream mouth (Bonnett \& Sykes, 2002; Jowett \& Richardson, 2003; Joy \& Death, 2004; Eikaas et al., 2005) was found for G. maculatus in the Santa Cruz River. Whilst these studies and other made in Chile (Colin et al., 2012; Garcíaet al., 2012) found other important variables influencing galaxiid abundance - substrate composition, velocity, plant cover, elevation, discharge, and cattle farming activities - the results might be related to species specific requirements, study area or the scale of the study. Same genera were found to be associated with different habitat types in the same study area (Jowett \& Richardson, 2003; Joy \& Death, 2004; Jellyman et al., 2013) which might be related to niche differentiation. Regarding study areas, New Zealand and Chilean watercourses have a developed riparian area and might exhibit macrophyte accumulations which strongly differ from those in the Santa Cruz River, where vegetation cover is not present. Since this study tried to understand large scale patterns, other variables (e.g., substrate composition) which might have importance at microhabitat scale could be responsible for some abundance peaks visualized along $30-50 \mathrm{~km}$ reaches.

The results found, primarily the decrease in G. maculatus with the distance to the sea, were expected since this species represents landlocked and diadromous populations that spawn in the Santa Cruz estuary and then move up to the mid and downstream river areas (Carrea et al., 2013). Moreover, McDowall (2000) explained that $G$. maculatus communities were generally confined to low altitudes close to the sea due tothe poor swimming 
ability of this species. The rapid decrease with maximum depth to $10 \mathrm{~m}$ is consistent with the preference of this species forshallow waters and littoral areas. Also, prediction models using distance from the Lake Argentino, maximum depth and river wet width or these variables plus the river sinuosity captured the large-scale shape of the distribution of river along the river. Whilethe percentages of prediction error slightly differed, the sinuosity added another factor to the model related to the hydraulics, turbulence, and flow disturbance (Biggs, Nikora, \& Snelder, 2005; Jellyman, Brooker, \& McIntosh, 2013) which might change with the implementation of the hydroelectric dams. A high sinuosity value was identified as a positive factor in providing different microhabitats during the early ontogenetic development of the fish, and refuges along inshore retention areas during high discharge periods (Sedell, Reeves, Hauer, Stanford, \& Hawkins, 1990; Schiemer, Keckeis, Reckendorfer, \& Winkler, 2001; Hildrew, 1996).

Once regulated, therivers experience controlled changes in hydrology that modify the sinuosity and consequently the shape of the inshore, where dramatically high discharge events lead to wash-out effects, causing high mortality and a unidirectional, downstream shift of the fish population (Schiemer et al., 2001; Jellyman \& McIntosh, 2010). The effect of disturbance are especially evident in smaller species or stages; particularly, $G$. maculatus swimming performance from New Zealand showed that the degree of fish-turbulence interaction may depend on both the turbulence energy and size of fish (Nikora, Aberle, Biggs, Jowett, \& Sykes, 2003). The two dams to be built on the Santa Cruz will have another great impact on fish population: the obliteration of $51 \%$ of the current lotic environment, and the flooding of the most productive sections of the river (Tagliaferro et al., 2013). No information about possible development of fish passages for management projects wasavailable. However, G. maculatus showed to utilize a wide diversity of habitats of rivers and lakes (Barriga, Battini, Macchi, Milano, \& Cussac, 2002; Cussac et al., 2004; Valdovinos et al., 2012). In consequence, we expect that most diadromous specimens willrestrict their development to the lower basin; while in the lake-dam basins we expect to find landlocked populations associated with the littoral zone.

In conclusion, within the main-stem of the Santa Cruz River, G. maculatus was more abundant close to the sea and used shallow waters avoiding wide river areas.Since in other environments Galaxiids in general showed a strong preference for debris damsand waters covered with macrophytes, we anticipatethat G. maculatus above the dams toacclimate to those conditions and develop viable populations. Though the stability of these populations will depend on the operation of the dams and how that affects the exposure to predation and the availability of food resources.

The informationfrom this study can form a basis for the developmentand application of viable strategies for managingpopulations and habitats, and for ensuring theprotection of the species. A larger supply of preferred habitats will provide better conditions for G. maculatus success, preservation or restoration (Garcia et al., 2012). In addition, water regulation should be performed in a way that replicates the natural seasonal flow cycle as closely as possible (Carlisle, Wolock, \& Meador, 2010; Carlisle, Nelson, \& Eng, 2012; Ward \& Stanford, 1982) and fish passage construction should be consider to promote genetic exchange between populations separated by dams.

\section{References}

Akbaripasand, A., Nichol, E. C., Lokman, P. M., \& Closs, G. P. (2011). Microhabitat use of a native New Zealand galaxiid fish, Galaxias fasciatus. New Zealand Journal of Marine and Freshwater Research, 45(1), 135-144. http://dx.doi.org/10.1080/00288330.2010.544044

Allibone, R. M., \& Townsend, C. R. (1997). Distribution of four recently discovered galaxiid species in the Taieri River, New Zealand: the role of macrohabitat. Journal of Fish Biology, 51, 1235-1246. http://dx.doi.org/10.1111/j.1095-8649.1997.tb01140.x

APHA. (1994). Standard Methods for the examination of water and wastewater. Hanover, Maryland, USA: American Public Health Association.

Argent, D. G., Bishop, J., Stauffer, J. R., Carline, R. F., \& Myers, W. L. (2003). Predicting freshwater fish distributions using landscape-level variables. Fisheries Research, 60(1), 17-32. http://dx.doi.org/10.1016/S0165-7836(02)00076-0

Ault, T. R., \& White, R. W. G. (1994). Effects of Habitat Structure and the Presence of Brown Trout on the Population Density of Galaxias truttaceus in Tasmania, Australia. Trans. Am. Fish. Soc., 123(6), 939-949. http://dx.doi.org/10.1577/1548-8659(1994)123\%3C0939:EOHSAT\%3E2.3.CO;2

Baker, C. F., \& Smith, J. P. (2007). Habitat use by banded kokopu (Galaxias fasciatus) and giant kokopu (G. argenteus) co-occurring in streams draining the Hakarimata Range, New Zealand. New Zealand Journal of 
Marine and Freshwater Research, 41(1), 25-33. http://dx.doi.org/10.1080/00288330709509893

Barriga, J., Battini, M., Macchi, P., Milano, D., \& Cussac, V. (2002). Spatial and temporal distribution of landlocked Galaxias maculatus and Galaxias platei (Pisces: Galaxiidae) in a lake in the South American Andes. N. Z. J. Mar. Fresh. Res., 36, 345-359. http://dx.doi.org/10.1080/00288330.2002.9517092

Barton, K. (2013). MuMIn: Multi-model inference. Retrieved from http://cran.r-project.org/web/packages/MuMIn/index.html

Biggs, B. J. F., Nikora, V. I., \& Snelder, T. H. (2005). Linking scales of flow variability to lotic ecosystem structure and function. River Research and Applications, 21(2-3), 283-298. http://dx.doi.org/10.1002/rra.847

Bond, N. R., \& Lake, P. S. (2003). Characterizing fish - habitat associations in streams as the first step in ecological restoration. Austral Ecology, 28, 611-621. http://dx.doi.org/10.1046/j.1442-9993.2003.t01-1-01317.x

Bonnett, M. L., \& Sykes, J. R. E. (2002). Habitat preferences of giant kokopu, Galaxias argenteus. New Zealand Journal of Marine and Freshwater Research, 36(1), 13-24. http://dx.doi.org/10.1080/00288330.2002.9517067

Bown, L. R. (2000). Fish communities and their associations with environmental variables, lower San Joaquin River drainage, California. Environmental Biology of Fishes, 57, 251-269. http://dx.doi.org/10.1023/A:1007660914155

Brunet, F., Gaiero, D., Probst, J. L., Depetris, P. J., Gauthier-Lafaye, F., \& Stille, P. (2005). $813 \mathrm{C}$ tracing of dissolved inorganic carbon sources in Patagonian rivers (Argentina). Hydrol.Process., 19(17), 3321-3344. http://dx.doi.org/10.1002/hyp.5973

Carlisle, D. M., Nelson, S. M., \& Eng, K. (2012). Macroinvertebrate community condition associated with the severity of streamflow alteration. River Res. Applic..

Carlisle, D. M., Wolock, D. M., \& Meador, M. R. (2010). Alteration of streamflow magnitudes and potential ecological consequences: a multiregional assessment. Front. Ecol. Environ., 9, 264-270. http://dx.doi.org/10.1890/100053

Carrea, C., Cussac, V. E., \& Ruzzante, D. E. (2013). Genetic and phenotypic variation among Galaxias maculatus populations reflects contrasting landscape effects between northern and southern Patagonia. Freshwater Biol., 58(1), 36-49. http://dx.doi.org/10.1111/fwb.12036

Colin, N., Piedra, P., \& Habit, E. (2012). Variaciones espaciales y temporales de las comunidades ribereñas de peces en un sistema fluvial no intervenido: Río San Pedro, Cuenca del Río Valdivia (Chile). Spatial and temporal distribution of riparian fish communities in an undisturbed fluvial system: the San Pedro River, Valdivia basin (Chile). Gayana, 75(2), 24-35.

Cussac, V. E, Ortubay, S., Iglesias, G., Milano, D., Lattuca, M. E., Barriga, J. P., ... Gross, M. (2004). The distribution of South American galaxiid fishes: the role of biological traits and post-glacial history. Journal of Biogeography, 31, 103-121. http://dx.doi.org/10.1046/j.0305-0270.2003.01000.x

Eikaas, H. S., Kliskey, A. D., \& McIntosh, A. R. (2005). Environmental assessment. Spatial modeling and habitat quantification for two diadromous fish in New Zealand streams: A GIS-Based Approach with Application for Conservation Management. Environ. Manage., 36(5), $726-740$. http://dx.doi.org/10.1007/s00267-004-0208-5

García, A., González, J., \& Habit, E. (2012). Caracterización del hábitat de peces nativos en el río San Pedro (cuenca del rio Valdivia, Chile). Habitat characterization of native fish in the San Pedro River (Valdivia River basin, Chile). Gayana, 75(2), 36-44. http://dx.doi.org/10.4067/S0717-65382012000100004

Gordon, N. D., McMahon, T. A., Finlayson, B. L., Gippel, C. J., \& Nathan, R. J. (2004). Stream Hydrology. An Introduction for Ecologists. Sussex, England: John Wiley and Sons Ltd..

Guisan, A., \& Zimmermann, N. E. (2000). Predictive habitat distribution models in ecology. Ecol. Model., 135, 147-186. http://dx.doi.org/10.1016/S0304-3800(00)00354-9

Hale, R., Downes, B. J., \& Swearer, S. E. (2008). Habitat selection as a source of inter-specific differences in recruitment of two diadromous fish species. Freshwater Biol., 53, 2145-2157.

Hildrew, A. G. (1996). Whole river ecology: spatial scale and heterogeneity in the ecology or running waters. 
Arch. Hydrobiol. Suppl. 113, Large Rivers, 10, 25-43.

Hynes, H. B. N. (1970). The ecology of running waters (p. 555). Toronto, Canada: University of Toronto Press.

Jellyman, P. G., \& McIntosh, A. R. (2008). The influence of habitat availability and adult density on non-diadromousgalaxiid fry settlement in New Zealand. J. Fish Biol., 72, 143-156. http://dx.doi.org/10.1111/j.1095-8649.2007.01694.x

Jellyman, P. G., \& McIntosh, A. R. (2010). Recruitment variation in a stream galaxiid fish: multiple influences on fry dynamics in a heterogeneous environment. Freshwater Biol., 55, 1930-1944. http://dx.doi.org/10.1111/j.1365-2427.2010.02427.x

Jellyman, P. G., Brooker, D. J., \& McIntosh, A. R. (2013). Quantifying the direct and indirect effects of disturbance on stream fish assemblages. Freshwater Biology, 58, 2614-2631. http://dx.doi.org/10.1111/fwb.12238

Jowett, I. G., Richardson, J., \& Bonnett, M. L. (2005). Relationship between flow regime and fish abundances in a gravel-bed river, New Zealand. J. Fish Biol., 66, 1419-1436. http://dx.doi.org/10.1111/j.0022-1112.2005.00693.x

Jowett, I. G., \& Richardson, J. (2003). Fish communities in New Zealand rivers and their relationship to environmental variables. New Zealand Journal of Marine and Freshwater Research, 37, 347-366. http://dx.doi.org/10.1080/00288330.2003.9517172

Joy, M. K., \& Death, R. G. (2004). Predictive modelling and spatial mapping of freshwater fish and decapod assemblages using GIS and neural networks. Freshwater Biology, 49, 1036-1052. http://dx.doi.org/10.1111/j.1365-2427.2004.01248.x

McDowall, R. M. (1990). New Zealand freshwater fishes, a natural history and guide (p. 553). Auckland, New Zealand: Heinemann-Reed.

McDowall, R. M. (2000). The Reed field guide to New Zealand freshwater fishes (p. 224). Auckland: Reed Books.

Montoya, G., Jara, A., Solis-Lufí, K., Colin, N., \& Habit, E. (2012). Primeros estadiosdelciclo de vida de pecesnativos del río San Pedro (Cuenca del río Valdivia, Chile). Gayana, 76(Número Especial), 86-100. http://dx.doi.org/10.4067/S0717-65382012000100008

Nikora, V. I., Aberle, J., Biggs, B. J. F., Jowett, I., \& Sykes, J. R. E. (2003). Effects of fish size, time-to-fatigue, and turbulence on swimming performance: a case study of Galaxias maculatus(inanga). J. Fish Biol., 63, 1365-1382. http://dx.doi.org/10.1111/j.1095-8649.2003.00241.x

Poff, N. L., \& Ward, J. V. (1990). Physical habitat template of lotic systems: Recovery in the context of historical pattern of spatiotemporal heterogeneity. Environmental Management, 14(5), 629-645. http://dx.doi.org/10.1007/BF02394714

Power, M. E., Stout, R. J., Cushing, C. E., Harper, P. P., Hauer, F. R., Matthews, W. J., ... Wais De Badgen, I. R. (1988). Biotic and abiotic controls in river and stream communities. Journal of the North American Benthological Society, 7, 456-479. http://dx.doi.org/10.2307/1467301

$\mathrm{R}$ Development Core Team. (2012). R: A language and environment for statistical computing. Vienna, Austria: $\mathrm{R}$ Foundation for statistical Computing. Retrieved from http://www.R-project.org/

Resh, V. H., Brown, A. V., Covich, A. P., Gurtz, M. E., Li, H. W., Minshall, G. W., .. Wissmar. R. (1988). The role of disturbance in stream ecology. Journal of the North American Benthological Society, 7, 433-455. http://dx.doi.org/10.2307/1467300

Schiemer, F., Keckeis, H., Reckendorfer, W., \& Winkler, G. (2001). The "inshoreretention concept" and itssignificanceforlargerivers. Arch. Hydrobiol., 12(2-4), 509-516.

Sedell, J. R., Reeves, G. H., Hauer, F. R., Stanford, J. A., \& Hawkins, C. P. (1990). Role of refugia in recovery from disturbances: modern fragmented and disconnected river systems. Env. Managem., 14, 711-724. http://dx.doi.org/10.1007/BF02394720

Tagliaferro, M., Miserendino, M. L., Liberoff, A. L., Quiroga, P., \& Pascual, M. A. (2013). Dams in the last large free-flowing rivers of Patagonia, the Santa Cruz River, environmental features, and macroinvertebrate community. Limnologica, 43, 500-509. http://dx.doi.org/10.1016/j.limno.2013.04.002

Valdovinos, C., Habit, E., Jara, A., Piedra, P., González, J., \& Salvo, J. (2012). Dinámica espacio-temporal de 13 
especies de peces nativos en un ecotono lacustre-fluvial de la Cuenca del Río Valdivia (Chile). Spatio-temporal dynamics of 13 species of native fish in a lake - river ecotone in the Valdivia River Basin (Chile). Gayana, Especial, 45-58.

Ward, J. V., \& Stanford, J. A. (1983). The intermediate disturbance hypothesis: an explanation for biotic diversity patterns in lotic ecosystems. In T. D. Fontaine III \& S. M. Bartel (Eds.), Dynamics of lotic ecosystems (pp. 347-356). Michigan: Ann Arbor Press, Ann Arbor.

Wolman, M. G. (1954). A method of sampling coarse river-bed material. Transactions, American Geophysucal Union, 35(6), 951-956. http://dx.doi.org/10.1029/TR035i006p00951

\section{Copyrights}

Copyright for this article is retained by the author(s), with first publication rights granted to the journal.

This is an open-access article distributed under the terms and conditions of the Creative Commons Attribution license (http://creativecommons.org/licenses/by/3.0/). 